\title{
TAKING ADVANTAGE OF A NEW HYDRAULIC INFRASTRUCTURE TO STUDY THE SEDIMENT YIELD IN A SMALL BASIN OF CENTRAL SPAIN
}

\author{
E. MOLINA-NAVARRO ${ }^{*}$, S. MARTÍNEZ-PÉREZ ${ }^{1}$, \\ A. SASTRE-MERLÍN ${ }^{1}$, R. BIENES-ALLAS ${ }^{2}$ \\ ${ }^{1}$ Universidad de Alcalá. Departamento de Geografía, Geología y Medio Ambiente. \\ Unidad Docente de Geología. Facultad de Ciencias \\ Ctra. Madrid-Barcelona Km. 33.6, 28871 Alcalá de Henares, Madrid, España. \\ ${ }^{2}$ Instituto Madrileño de Investigación y Desarrollo Rural, Agrario y Alimentario (IMIDRA). \\ Apto. de Correos 127, 28800 Alcalá de Henares, Madrid, España.
}

\begin{abstract}
Predicting the sediment yield at a catchment scale is one of the main challenges regarding fluvial geomorphology, however, it involves some difficulties. In this study, we have taken advantage of the construction of a new hydraulic infrastructure to study the sediment yield in its drainage basin between 2007 and 2010. This infrastructure is a small dam constructed in the riverine zone of the Entrepeñas Reservoir (upper Tagus catchment, central

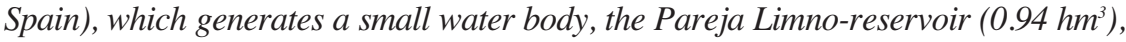
with a drainage area of $88 \mathrm{~km}^{2}$. It was built to mitigate the environmental and socioeconomic impacts of the construction and use of the Entrepeñas Reservoir,
\end{abstract} including the "arid band" phenomenon.

Sediment yield was studied taking three sediment cores in the shallowest section, the central part and the deepest zone of the limno-reservoir. The layer of surface sediment was analized and a decreasing thickness of sediment towards the deepest zone of the limno-reservoir was observed. After assigning an area of the limno-reservoir to each core record, estimated annual sedimentation rate was $2032 \mathrm{Mg}$ year $^{-1}$, which supposes an annual storage capacity loss around $0.3 \%$ and a specific sediment yield in the drainage basin around $0.23 \mathrm{Mg} \mathrm{ha}^{-1}$ year ${ }^{-1}$. Comparing this value with previous soil loss studies performed in the basin, sediment delivery ratio in the basin varies from $2.2 \%$ to $3.8 \%$.

Both sediment yield and sediment delivery ratio showed low values for the Mediterranean context. The characteristics of the basin (small area, elongated shape with one main river channel, abundant vegetation), the absence of other erosive processes than rill and interrill erosion and the lower aggressiveness of rainfall in the center of the Iberian Peninsula may explain these results. The presence of the National Road N-204 surrounding the limno-reservoir may play a role in the low sediment delivery, especially from the adjoining hillslopes. 


\section{Aprovechamiento de una nueva infraestructura hidráulica para el estudio de la producción de sedimentos en una pequeña cuenca del centro de España}

RESUMEN. En geomorfología fluvial, la estimación de la producción de sedimentos a escala de cuenca es uno de los grandes retos, aunque no exento de dificultades. En este estudio se ha aprovechado la oportunidad que brinda la construcción de una nueva infraestructura hidráulica para estudiar la producción de sedimentos en su cuenca vertiente entre 2007 y 2010. Se trata de un dique construido en una zona de cola del embalse de Entrepeñas (cuenca alta del Tajo), el cual genera una pequeña masa de agua, el limnoembalse de Pareja (de $0.94 \mathrm{hm}^{3}$ y con una cuenca vertiente de $88 \mathrm{~km}^{2}$ ). Su objetivo es mitigar los impactos ambientales y socioeconómicos generados por la construcción y explotación del embalse de Entrepeñas, incluido el fenómeno de "banda árida”.

La producción de sedimentos fue estudiada mediante la toma de tres testigos de sondeo, uno en la zona más superficial, otro en el sector intermedio del limno-embalse y el último en la zona más profunda. Se analizó la capa de sedimento superficial y se observó una reducción del su espesor hacia la zona de presa. Se asignó un sector del limno-embalse a cada testigo y se estimó una tasa de sedimentación anual de $2032 \mathrm{Mg}$ año ${ }^{-1}$, lo que supone una pérdida anual de volumen en torno al $0.3 \%$ y una producción específica de sedimentos aproximada en la cuenca de $0.23 \mathrm{Mg} \mathrm{ha}^{-1}$ año-1. Comparando estos valores con estudios de erosión de suelo que se han llevado a cabo en la cuenca con anterioridad, la tasa de suministro de sedimentos en la cuenca oscila entre un $2.2 \%$ y un $3.8 \%$.

En comparación con los valores habituales en el contexto mediterráneo, tanto la producción de sedimentos como el porcentaje de los mismos que alcanza el limnoembalse muestran valores bajos. Ello puede deberse a las características de la cuenca (área pequeña, forma alargada con un río principal, abundante vegetación), la ausencia de otros tipos de erosión aparte de la erosión laminar y en regueros y la menor agresividad de la lluvia en el centro de la Península Ibérica. Además, la Carretera Nacional N-204 rodea el limno-embalse, lo que puede ser un factor añadido al bajo aporte de sedimentos, especialmente desde las laderas adyacentes.

Key words: catchment sediment yield, limno-reservoir, Mediterranean, reservoir siltation, sediment delivery ratio.

Palabras clave: limnoembalse, mediterráneo, aterramiento de embalses, producción de sedimentos a escala de cuenca, tasa de transporte de sedimentos.

Received 17 November 2013 Accepted 20 February 2014

*Corresponding author: E-mail: eugenio.molina@uah.es/eugenio.molinanavarro @gmail.com 


\section{Introduction}

The prediction of sediment yield at a catchment scale is one of the most crucial and interesting challenges in fluvial geomorphology. Soil erosion and sediment yield are processes which pose significant environmental conservation threats, and they can be strongly accelerated by land use and climate change (Alatorre et al., 2010). Besides, Spain is one of the countries most severely affected by soil erosion in the European Mediterranean region (Solé Benet, 2006; García-Ruiz et al., 2013), being one of the most prominent environmental issues in the country (García Ruiz and López Bermúdez, 2009). Thus, siltation of Mediterranean reservoirs may be a significant problem (Navas et al., 2004).

Carrying out sediment yield studies at a catchment scale involves some difficulties. Erosion studies are relatively abundant and may include a large variety of methodologies: geomorphological transects, erosion pins, erosion profilers, soil loss plots, experimental basins, bathymetries or models, among others (García Ruiz and López Bermúdez, 2009). However, many of them may be not appropriate to work at a catchment scale (de Vente et al., 2005), and it is not easy to establish the relationship between soil erosion and total sediment yield at the outlet of a catchment. Not all eroded sediments reach the outlet of a drainage basin as a significant proportion is generally deposited at intermediate sites depending on multiple factors (Alatorre et al., 2010). Semi-quantitative approaches and regression equations have been tested recently to study the sediment yield in Spanish reservoirs, although these methodologies have been mostly calibrated for large basins (de Vente et al., 2011).

In 2006, a small dam was constructed in the riverine zone of the Entrepeñas Reservoir (Guadalajara, central Spain), next to the village of Pareja. It generates a small water body aimed to preserve a constant water level to mitigate the negative impacts caused by the construction and exploitation of the Entrepeñas Reservoir, which include the transfer of large water volumes to Southeast Spain. We have termed this kind of water bodies "limno-reservoirs", since they rather resemble a lake than an ordinary reservoir (Molina-Navarro et al., 2010).

The Pareja Limno-reservoir provides an excellent opportunity to research the sediment yield of its drainage basin, which main watercourse is the Ompólveda River. Sediment yield was studied with three sediment cores collected in the Pareja Limnoreservoir. Besides, prior to the study of sedimentation in the limno-reservoir, our investigation group carried out two erosion studies of the Ompólveda River basin. The first one, by Arévalo (2008), uses USLE and RUSLE models (Wischmeier and Smith $1965,1978)$, which are among the most popular methodologies to study soil erosion (e.g. Brath et al., 2002; Zarris et al., 2011). Applying the RUSLE equation and a modification of the USLE model, Arévalo found an average soil erosion between 9.4 and $10.6 \mathrm{Mg} \mathrm{ha}^{-1} \mathrm{year}^{-1}$. The second one uses an in-situ methodology, installing a monitoring network in the basin to study rill and interrill erosion and intermediate deposition. Average gross hillslope erosion estimated was around 6.0 $\mathrm{Mg} \mathrm{ha}^{-1}$ year-1 (Molina Navarro, 2013). The existence of previous erosion studies in the Ompólveda River basin allows us to estimate the sediment delivery ratio in the basin. 
The characteristics of the basin (abundant vegetation cover, small area, elongated shape) may favor a low connectivity with the stream network and sediment yield is expected to be low (de Vente et al., 2005). The sediment transported by the drainage network to the limno-reservoir may only constitute a small part of the gross erosion in the basin, and a considerable amount of eroded material can be deposited elsewhere, before reaching the limno-reservoir (Avendaño Salas et al., 1997). Moreover, the National Road N-204 surrounds the limno-reservoir and may trap most of the sediments produced in the adjoining hillslopes. In the Entrepeñas Reservoir -whose maximum water level area includes the Pareja Limno-reservoir-, sedimentation studies revealed that it is filled up at a rate of $0.5 \%$ per year (Palau Ybars, 2002). This value can be considered low, since for many reservoirs worldwide annual storage capacity loss can go up to 5\% (de Vente et al., 2005; Zarris et al., 2011).

The main objective of this paper is to estimate the sediment yield in the Ompólveda River basin through the study of sedimentation rates in the Pareja Limnoreservoir. Results obtained were compared with the erosion studies carried out in the basin, estimating its sediment delivery ratio.

\section{Material and methods}

\subsection{Study area}

The Pareja Limno-reservoir is located in the riverine zone of a sidearm of the Entrepeñas Reservoir (south of the Guadalajara Province, upper Tagus River Basin, Central Spain). It is adjacent to the village of the same name (Fig. 1). It has a capacity of $0.94 \mathrm{hm}^{3}$ and a potential inundation area of $26 \mathrm{ha}$. Its maximum water depth reaches $12.5 \mathrm{~m}$ in the dam zone, becoming progressively shallower towards the inflow section. It is fed by the Ompólveda River, whose main tributary is the Valdetrigo stream, flowing from the northeast.

The Ompólveda River basin covers an approximate area of $88 \mathrm{~km}^{2}$ within a Mediterranean climate region (annual average temperature around $13.0^{\circ} \mathrm{C}$ ). However, cold temperatures prevail in winter (daily average $\approx 5.0^{\circ} \mathrm{C}$ ) becoming warmer in summer (daily average $\approx 23.0^{\circ} \mathrm{C}$ ). Average annual precipitation recorded in the Escamilla station (in the upper catchment) is around $600 \mathrm{~mm}$, showing high intra- and inter-annual variability. Periods with maximum amount of rainfall do not follow a precise pattern and can be found in winter, spring or even in both seasons (MolinaNavarro et al., 2010). Storms are not as frequent and intense as in other Mediterranean areas, but may happen in summer or early autumn.

Altitude in the basin ranges from 718 to $1137 \mathrm{~m}$ a.s.l. in a rather small catchment, which means that the existing valleys have hillsides with high slopes (Fig. 1). The upper basin is dominated by a high limestone plateau from the Upper Miocene and more erodible and older sedimentary lithology outcrops in the hillsides of the Ompólveda River and its tributaries (intercalations of clay, marls, silt, sand, sandstone, conglomerates, 
limestone and gypsum, until the Late Cretaceous). Regarding soil types $61.5 \%$ of the catchment is covered by entisols and $38.5 \%$ by alfisols (Molina-Navarro et al., 2014).

The Ompólveda River basin has rural features. There are about 300 inhabitants in the area, most of them in the village of Pareja. Natural vegetation is the main land use in the catchment. $37 \%$ of the catchment is covered by forests, mainly combinations of pine and holm oak. $36 \%$ of the catchment is covered by scrubland, occasionally combined with pasture and $25 \%$ of the catchment are cultivated soils, mainly unirrigated cereal crops located in the flat limestone plateau. This makes the Ompólveda River basin representative of the small catchments of central Spain.

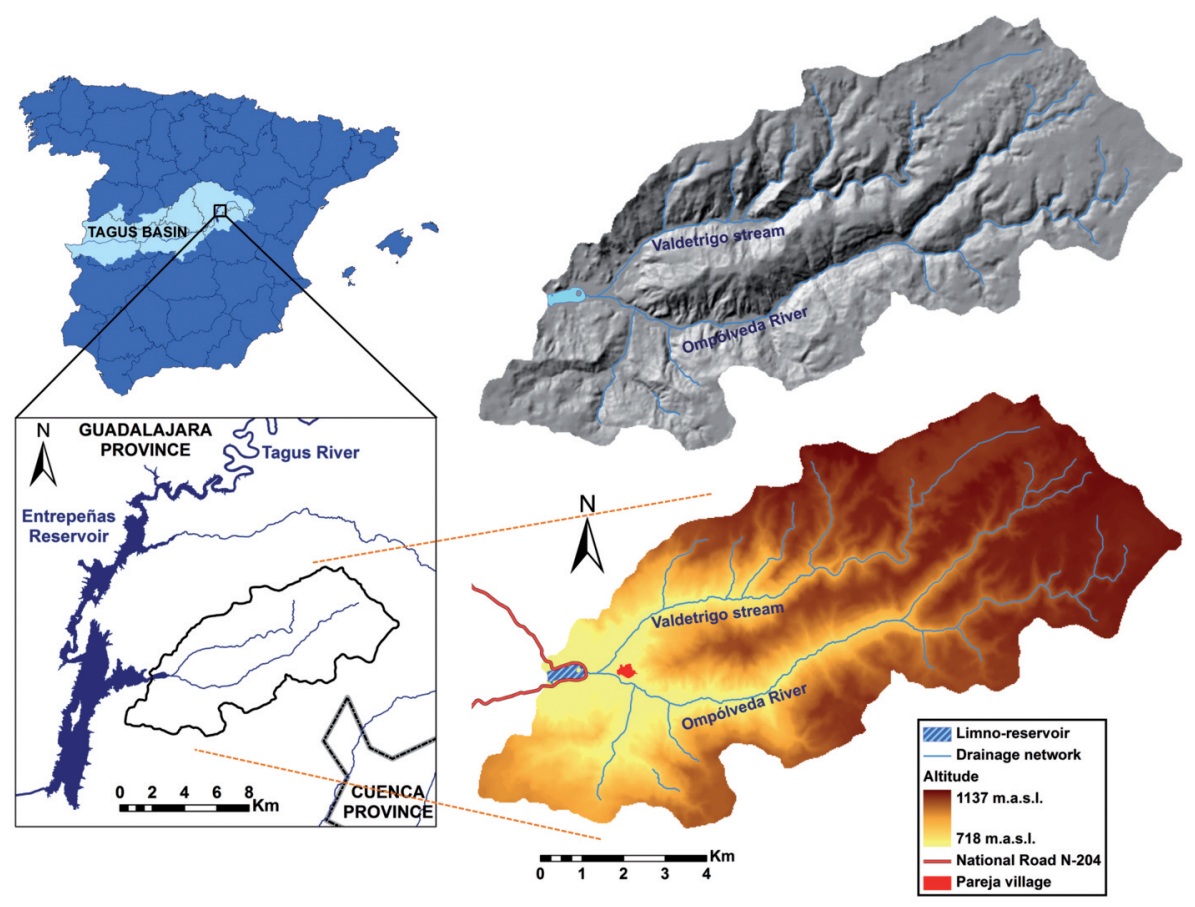

Figure 1. Location of the Pareja Limno-reservoir and its drainage basin, showing its digital elevation model and hillshade.

\subsection{Sediment yield}

Three sediment cores were taken from the Pareja Limno-reservoir to obtain an estimation of the sediment yield: one corresponding to the shallowest section $(1.5 \mathrm{~m}$ depth, $\left.\mathrm{N}^{\circ} 1\right)$, another in the central part of the limno-reservoir (5.0 m depth, $\left.\mathrm{N}^{\mathrm{o}} 2\right)$ and the last in the deepest zone (9.0 m depth, $\mathrm{N}^{\circ} 3$ ) (Fig. 2). The cores were collected with a cylindrical piston corer, equiped with a $6 \mathrm{~cm}$ diameter plastic core tube which was designed to leave cores intact (Fig. 3). 


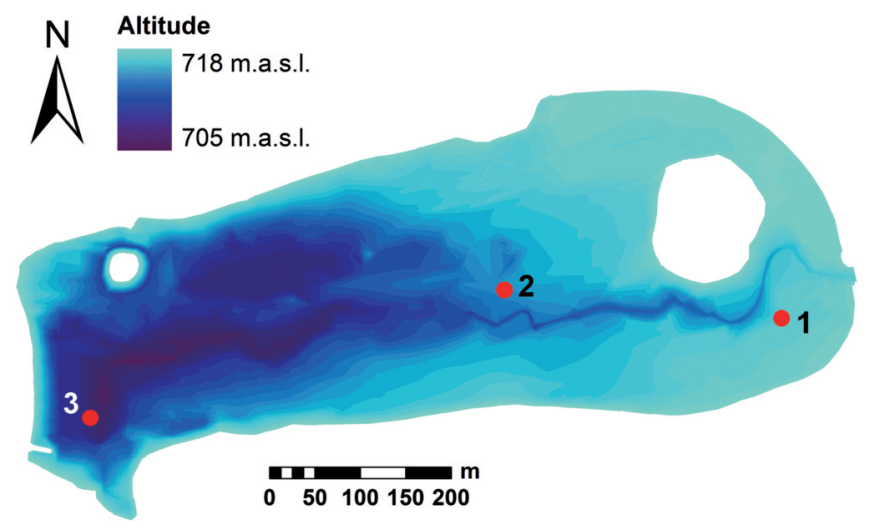

Figure 2. Result of the bathymetric survey carried out in the Pareja Limno-reservoir in autumn 2010 and sampling location of sediment cores ( $1=$ shallower section, $2=$ central part, $3=$ deepest zone).

In the laboratory, the layer of surface sediment in the cores was easily identified visually because of its lighter colour. Its thickness was measured in several points around the tube (three to seven, depending on the irregularity of the surface sediment bottom), obtaining the average thickness. One or two -when possible- sediment samples from each core were sectioned (1.5 or $2.0 \mathrm{~cm}$ thick) using a slicing disc (Fig. 4). Samples were oven dried at $105^{\circ} \mathrm{C}$ to constant weight over approximately $24 \mathrm{~h}$ to determine their dry bulk densities.
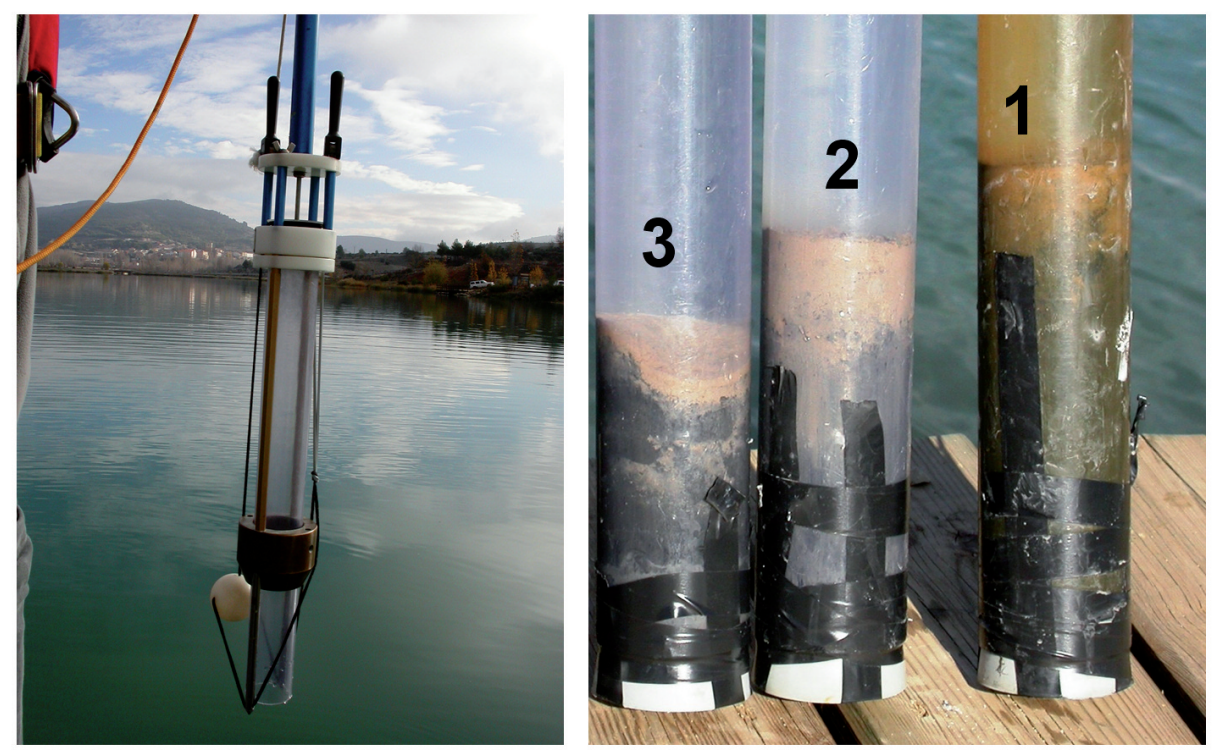

Figure 3. Cylindrical piston corer and samples collected in the Pareja Limno-reservoir. Numbers indicate the location of the cores (see Fig. 2). 


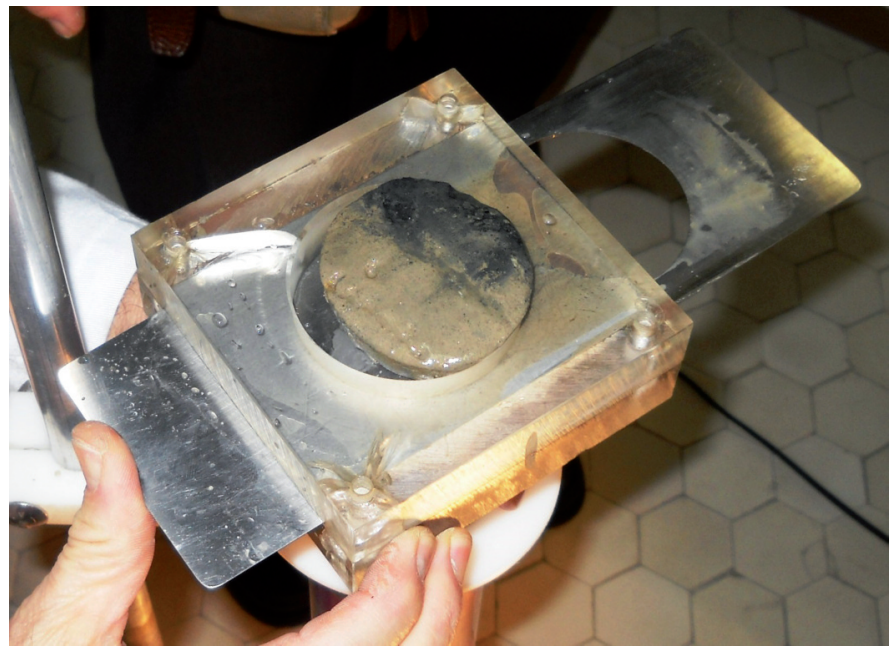

Figure 4. Slicing disc used to section the surface sediment cores.

According to Wetzel (2001), deposition of sediments decreases exponentially with increasing depth of the reservoir. Following this criteria, the limno-reservoir area was divided into three polygons using the output of a $0.5 \mathrm{~m}$ resolution bathymetry that was carried out in autumn 2010 (Fig. 2). The area of these polygons was assigned to each sedimentation record for calculations. The sediment cores were taken in November 2010 and the definitive filling of the Pareja Limno-reservoir started in July 2007. Using this time frame, the sediment thicknesses, the bulk densities and the limno-reservoir area assigned to each core, the sediment yield in the Ompólveda River basin was estimated. Following Verstraeten and Poesen (2000), $100 \%$ trap efficiency of the limno-reservoir was assumed considering the limnoreservoir area and the average Ompólveda River discharge measured in a gauging station that became inoperative after the construction of the limno-reservoir (MolinaNavarro et al., 2010; Molina-Navarro et al., 2014).

\subsection{Sediment delivery ratio}

Estimated sediment yield was compared to the gross erosion values obtained by our research group using USLE and RUSLE models (Arévalo, 2008) and an in-situ monitoring network (Molina Navarro, 2013). Finally, the sediment delivery ratio in the Ompólveda River basin was obtained and compared to values in the Spanish context.

\section{Results and discussion}

\subsection{Sediment yield}

The average thicknesses of surface sediment obtained for each sediment core were $4.50 \mathrm{~cm}$ in the shallowest section $\left(\mathrm{N}^{\circ} 1\right), 3.63 \mathrm{~cm}$ in the central part of the limno- 
reservoir $\left(\mathrm{N}^{\circ} 2\right)$ and $1.94 \mathrm{~cm}$ in the deepest zone $\left(\mathrm{N}^{\circ} 3\right)$. The fitness of these data to an exponential curve is shown in Fig. 5, while Fig. 6 shows the division of the limnoreservoir into three polygons considering this exponential adjustment and the $0.5 \mathrm{~m}$ resolution bathymetry. Areas of 11.0 ha, 9.1 ha and 4.6 ha were assigned to the shallow, central and deep surface sediment cores, respectively.

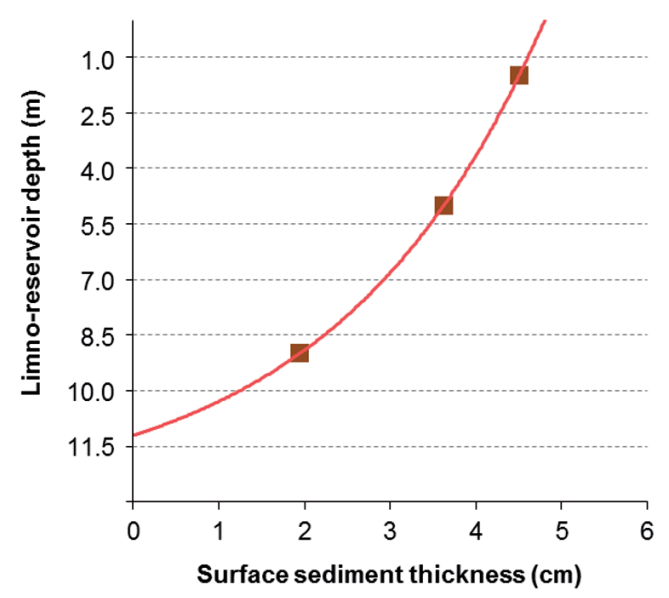

Figure 5. Fitness of the thicknesses of surface sediment samples and its depth to an exponential curve.

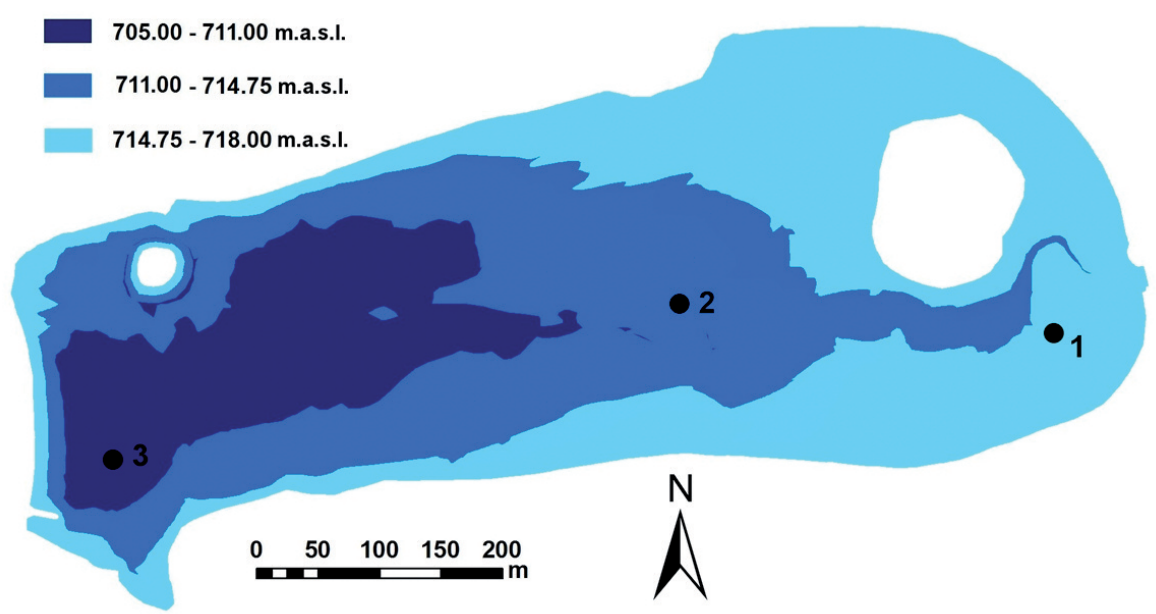

Figure 6. Division of the Pareja Limno-reservoir into three polygons considering the exponential adjustment in Fig. 5. 
After laboratory work, average bulk densities for each location were $0.82,0.73$ and $0.49 \mathrm{~g} \mathrm{~cm}^{3}$ for the shallow, central and deep surface sediment samples. Decreasing of density towards the deepest zone responds to the particle size gradient usually found in reservoir sediments, where only the smallest particles (clay size) may reach the deepest zone as decreasing water velocity and transport capacity (Palau Ybars, 2002; Navas et al., 2004). Since the time of deposition has been estimated in 3.4 years, we obtained a sedimentation rate in the Pareja Limno-reservoir of $2032 \mathrm{Mg}_{\text {year }}{ }^{-1}\left(2690 \mathrm{~m}^{3}\right.$ year $\left.^{-1}\right)$. This rate means an annual storage capacity loss around $0.3 \%$. The specific sediment yield of the Ompólveda River basin can be estimated around $0.23 \mathrm{Mg} \mathrm{ha}^{-1}$ year $^{-1}$.

Due to the physiographic characteristics of the study area, the sedimentation rate is low and in the same order of magnitude of the value found in the adjacent Entrepeñas Reservoir, filled up at a rate of $0.5 \%$ per year (Palau Ybars, 2002). Average annual storage capacity loss in Spanish reservoirs is also $0.5 \%$ per year, while in some reservoirs this value can go over $6 \%$, especially in the Mediterranean watershed and in the Canary Islands (Palau Ybars, 2002).

Avendaño Salas et al. (1997) revealed the existence of a relationship between drainage basin area and sediment yield in a sediment yield study carried out with data from 60 Spanish reservoirs. Thus, the small area of the limno-reservoir drainage basin may favor the low sediment yield. Other characteristics of the basin may play a role too. According to de Vente et al. (2005), an elongated shape with one main river channel draining to the limno-reservoir and a dense vegetation cover may result in low connectivity between the stream network and the limno-reservoir and, consequently, in low sediment yield. Besides, higher sediment delivery is expected in those areas where other erosion processes than rill and interrill erosion are also present, especially gully erosion (de Vente et al., 2008; Vanmaercke et al., 2012). Gullies, landslides or riverbank erosion processes are rare in our study area.

The Barasona Reservoir, whose siltation and catchment sediment yield has been studied in detail, may serve as an example. Although the lithology and land uses of the Barasona catchment (except for its upper catchment) are similar to those in our study area, the rate of sedimentation under lacustrine regime (11.6-18.12 $\mathrm{cm}_{\text {year }}{ }^{-1}$, Navas et al., 2004) is higher than in the Pareja Limno-reservoir $\left(1.1 \mathrm{~cm}\right.$ year $\left.{ }^{-1}\right)$. Estimates of 3.50 and $3.73 \mathrm{Mg} \mathrm{ha}^{-1}$ year $^{-1}$ for the specific sediment yield of the Barasona watershed (SanzMontero et al., 1996; Alatorre et al., 2010) are higher too. The higher values of sediment production may be related with characteristics that differ from our study area: higher size $\left(1504 \mathrm{~km}^{2}\right)$, the existence of badlands, the presence of dryland crops in the lowest part of the watershed or the greater importance of channel erosion in the upper catchment, which is characterized by a high mountain relief (Navas et al., 2004; Alatorre et al., 2010).

Basin characteristics may not be the only reason for the low sediment yield. Rainfall events show lower intensity in the centre of the Iberian Peninsula than in other Mediterranean areas, decreasing sediment transport (López Moreno, 2006). Results obtained by Avendaño Salas et al. (1997) in Spain are consistent with this fact. They 
obtained specific sediment yield values ranging from 0.08 to $27.03 \mathrm{Mg} \mathrm{ha}^{-1}$ year $^{-1}$, and averaging the values in the large rivers, the lowest yields were found in the Douro and Tagus basins, located in central Spain (1.95 and 2.66 $\mathrm{Mg} \mathrm{ha}^{-1}$ year $^{-1}$, respectively). It may also explain the higher sediment yield in the Barasona catchment, where storms are common and average annual precipitation is higher (even more than $2000 \mathrm{~mm}$ in the headwaters, Alatorre et al., 2010).

The National Road N-204 surrounding the Pareja Limno-reservoir (Fig. 1) may also contribute to the low sediment yield value obtained. According to de Vente et al. (2005), the areas close to a reservoir or else with a good connectivity to the reservoir are the most important source areas for sediments at the basin outlet. The same conclusion was found by López-Vicente and Navas (2010) in a lake endorheic catchment in the Spanish Pre-Pyrenees. The presence of the road minimizes the contribution of these areas, making negligible the sediment delivery from the hillslopes adjoining the limno-reservoir.

\subsection{Sediment delivery ratio}

The comparison of the estimated sediment yield in the Ompólveda River basin $\left(0.23 \mathrm{Mg} \mathrm{ha}^{-1}\right.$ year $\left.^{-1}\right)$ with the gross erosion values obtained in previous studies in the catchment (Arévalo, 2008; Molina Navarro, 2013) results in a sediment delivery ratio in the basin varying from $2.2 \%$ to $3.8 \%$. Eroded sediments may be deposited at field boundaries, footslopes as colluvium, floodplains, valley bottoms, depressions or perched flat areas before reaching the limno-reservoir (de Vente et al., 2005; Alatorre et al., 2010; Vanmaercke et al., 2012).

Taking gross erosion data determined by ICONA (1987) using the USLE, Avendaño Salas et al. (1997) determined the sediment delivery ratios for 37 catchment areas throughout Spain, ranging from $0.8 \%$ to $67.5 \%$. Using also Avendaño Salas et al. (1997) results as starting point but estimating gross erosion with a RUSLE approach, de Vente et al. (2008) predicted ratios varying from $0.3 \%$ to $55.5 \%$. In the abovementioned Barasona catchment, the estimated ratio is around 10\% (Alatorre et $a l ., 2010)$. The sediment delivery ratio obtained in our study is in a low range compared with these results, consequence of the aforementioned low sediment connectivity in the basin, the near absence of other erosion processes than rill and interril erosion and the presence of the National Road N-204 surrounding the limno-reservoir. When catchment characteristics are the opposite, sediment delivery ratio may be higher. In the Estaña catchment, located in the Spanish Pre-Pyrenees, the presence of gullies and high slopes, the low percentage of flat areas, its endorheic configuration and the efficiency of hillslopes and ephemeral streams near the lakes favoured a high average sediment delivery ratio (41\%, López-Vicente and Navas, 2010).

It must be acknowledged that our study covered a time frame of 3.4 years (July 2007-November 2010) and results must be taken with caution regarding temporal representativeness since largest sediment yields in Mediterranean environments are produced by the largest rainy events (Bussi et al., 2013). Nevertheless, our study 
covered the three precipitation year-types (average precipitation in the basin is around $600 \mathrm{~mm}$ and 2007/08 was normal $-555 \mathrm{~mm}-$, 2008/09 was dry $-462 \mathrm{~mm}-$, and 2009/10 was wet $-707 \mathrm{~mm}-$ ). Moreover, rainfall erosivity is lower in central Spain than in other Mediterranean regions (Lopez Moreno, 2006), giving some assurance to our results.

\section{Conclusions}

A low sedimentation rate was found in the Pareja Limno-reservoir, whose annual storage capacity loss has been estimated in $0.3 \%$. The low sediment yield in the limnoreservoir drainage basin is favored by its characteristics: a small area, a significant natural vegetation cover and an elongated shape with one main river area. This seems to result in low connectivity between the stream network and the limno-reservoir. The presence of the National Road N-2004 surrounding the limno-reservoir is also responsible of the low sediment yield into the water body, mainly those sediments coming from the near hillslopes. The result obtained is consistent with the sedimentation rate measured in the adjoining Entrepeñas Reservoir ( $0.5 \%$ capacity loss per year).

Considering the soil loss studies performed in the Ompólveda River basin, we can estimate a sediment delivery ratio varying from $2.2 \%$ to $3.8 \%$, which is low compared to other values found in the literature for Spanish areas. The deposition of sediments elsewhere before reaching the limno-reservoir, the absence of other erosive process than rill and interrill erosion and the aforementioned reasons for a low sediment yield may explain the low sediment delivery ratio in the basin.

\section{Acknowledgements}

This research was funded by the "Obra Social" of Ibercaja Bank and the regional Government of Castilla-La Mancha (Science and Education Department, research project PAI08-0226-1758). Eugenio Molina-Navarro received additional support from a predoctoral grant from the University of Alcalá. The authors thank the Pareja City Council and the Confederación Hidrográfica del Tajo for their support.

\section{References}

Alatorre, L.C., Beguería, S., García-Ruiz, J.M. 2010. Regional scale modeling of hillslope sediment delivery: A case study in the Barasona Reservoir watershed (Spain) using WATEM/SEDEM. Journal of Hydrology 391, 109-123.

Arévalo, D. 2008. Estimación de la erosión del suelo en la cuenca del Ompólveda. Bachelor of Environmental Sciences thesis dissertation, Universidad de Alcalá, 85 pp.

Avendaño Salas, C., Sanz Montero, E., Cobo Rayán, R., Gómez Montaña, J.L. 1997. Sediment yield at Spanish reservoirs and its relationship with the drainage area. In Dix-neuviène Congrès des Grands Barrages. Commission Internationale Des Grands Barrages, Florence, pp. 863-874. 
Brath, A., Castellarin, A., Montanari, A. 2002. Assessing the effects of land-use changes on annual average soil losses. Hydrology and Earth System Sciences 6(2), 255-265.

Bussi, G., Rodríguez-Lloveras, X., Francés, F., Benito, G., Sánchez-Moya, Y., Sopeña, A. 2013. Sediment yield model implementation based on check dam infill stratigraphy in a semiarid Mediterranean catchment. Hydrology and Earth System Sciences 17, 3339-3354.

García Ruiz, J. M., López Bermúdez, F. 2009. La erosión del suelo en España. Sociedad Española de Geomorfología, Zaragoza, 441 pp.

García-Ruiz, J.M., Nadal Romero, E., Lana-Renault, N., Beguería, S. 2013. Erosion in Mediterranean landscapes: Changes and future challenges. Geomorphology 198, 20-36.

de Vente, J., Poesen, J., Verstraeten, G. 2005. The application of semiquantitative methods and reservoir sedimentation rates for the prediction of basin sediment yield in Spain. Journal of Hydrology 305, 63-86.

de Vente, J., Poesen, J., Verstraeten, G., Van Rompaey, A., Govers, G. 2008. Spatially distributed modelling of soil erosion and sediment yield at regional scales in Spain. Global and Planetary Change 60, 393-415.

de Vente, J., Verduyn, R., Verstraeten, G., Vanmaercke, M., Poesen, J. 2011. Factors controlling sediment yield at the catchment scale in NW Mediterranean geoecosystems. Journal of Soils and Sediments 11, 690-707.

ICONA (Instituto para la Conservación de la Naturaleza) 1987. Mapas de Estados Erosivos. Ministerio de Agricultura, Pesca y Alimentación, Madrid.

López Moreno, J.I. 2006. Cambio ambiental y gestión de los embalses en el Pirineo central español. Consejo de Protección de la Naturaleza de Aragón, Zaragoza, 208 pp.

López-Vicente, M., Navas, A. 2010. Relating soil erosion and sediment yield to geomorphic features and erosion processes at the catchment scale in the Spanish Pre-Pyrenees. Environmental Earth Sciences 61, 143-158.

Molina Navarro, E. 2013. Hydrology, limnology and environmental feasibility of the Pareja Limno-reservoir. $\mathrm{PhD}$ thesis dissertation, Universidad de Alcalá, $224 \mathrm{pp}$.

Molina-Navarro, E., Martínez Pérez, S., Sastre Merlín, A. 2010. El limnoembalse de Cola de Pareja (Guadalajara): Aspectos medioambientales e hidrológicos. Boletín Geológico y Minero 121(1), 69-80.

Molina-Navarro, E., Martínez-Pérez, S., Sastre-Merlín, A., Bienes-Allas, R. 2014. Hydrologic Modeling in a Small Mediterranean Basin as a Tool to Assess the Feasibility of a LimnoReservoir. Journal of Environmental Quality 43, 121-131.

Navas, A., Valero Garcés. B., Machín, J. 2004. An approach to integrated assessment of reservoir siltation: the Joaquín Costa reservoir as a case of study. Hydrology and Earth System Sciences 8(6), 1193-1199.

Palau Ybars, A. 2002. La sedimentación en embalses. Medidas preventivas y correctoras. In $I$ Congreso de Ingeniería Civil, Territorio y Medio Ambiente, Vol. I. Colegio de Ingenieros de Caminos, Canales y Puertos, Madrid, pp. 847-856.

Sanz-Montero, M. E., Cobo-Rayán, R., Avendaño-Salas, C., Gómez-Montaña, J. 1996. Influence of the drainage basin area on the sediment yield to Spanish reservoirs. In Proceedings of the First European Conference and Trace Exposition on Control Erosion. International Erosion Control Association IECA, Sitges, Spain.

Solé Benet, A. 2006. Spain. In Soil Erosion in Europe, J. Boardman, J. Poesen (eds.), John Wiley and Sons, Chichester, England, pp. 501-513.

Vanmaercke, M., Maetens, W., Poesen, J., Jankauskas, B., Jankauskiene, G., Verstraeten, G., de Vente, J. 2012. A comparison of measured catchment sediment yields with measured and predicted hillslope erosion rates in Europe. Journal of Soils and Sediments 12, 586-602. 
Verstraeten, G., Poesen, J. 2000. Estimating trap efficiency of small reservoirs and ponds: methods and implications for the assessment of sediment yield. Progress in Physical Geography 24(2), 219-251.

Wetzel, R.G. 2001. Limnology. Lake and River Ecosystems, third ed. Academic Press-Elsevier, San Diego, 1006 pp.

Wischmeier, W.H., Smith, D.D. 1965. Predicting rainfall-erosion losses from cropland east of the Rocky Mountains. USDA, Washington, Agricultural Handbook No. 282, 47 pp.

Wischmeier, W.H., Smith, D.D. 1978. Predicting rainfall erosion losses: a guide to conservation planning. US Department of Agriculture, Washington, DC, Agriculture Handbook, 537, 58 pp.

Zarris, D., Vlastara, M., Panagoulia, D. 2011. Sediment Delivery Assessment for a Transboundary Mediterranean Catchment: The Example of Nestos River Catchment. Water Resources Management 25, 3785-3803. 